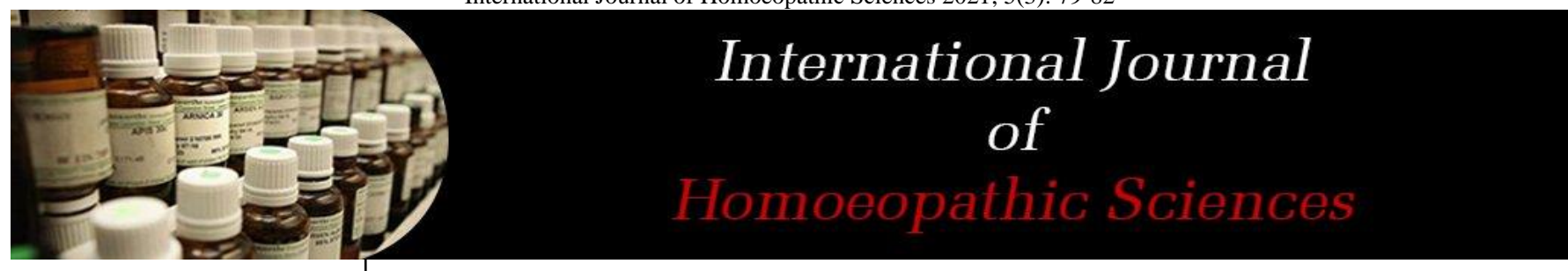

E-ISSN: $2616-4493$

P-ISSN: 2616-4485

www.homoeopathicjournal.com IJHS 2021; 5(3): 79-82

Received: 16-05-2021

Accepted: 18-06-2021

Dr. AT Senthil Kumar B.H.M.S, M.D (HOM) Professor, PG Guide, Head of Department, Department of Materia Medica, Vinayaka Mission's Homoeopathic Medical College \& Hospital, A Constituent college of VMRFDeemed to be University, Salem, Tamil Nadu, India

Dr. G Geetha Sudha Reddy Post Graduate Student, Department of Materia Medica, Vinayaka Mission's Homoeopathic Medical College \& Hospital, A Constituent college of VMRF-Deemed to be University, Salem,

Tamil Nadu, India
Corresponding Author: Dr. AT Senthil Kumar B.H.M.S, M.D (HOM), Professor, PG Guide, Head of Department, Department of Materia Medica, Vinayaka Mission's Homoeopathic Medical College \& Hospital, A Constituent college of VMRFDeemed to be University, Salem, Tamil Nadu, India

\section{Anemia and its homoeopathic management}

\author{
Dr. AT Senthil Kumar and Dr. G Geetha Sudha Reddy
}

DOI: $\underline{\text { https://doi.org/10.33545/26164485.2021.v5.i3b.409 }}$

Abstract

In India Anemia is more prevalent and case rate is very high compared to world average. More than half of India's children and women are anemic according to national family health survey 2019-20. There is a dire need to look into causes and prevention of anemia. With regular care and proper diet, we can reduce anemic cases easily. In this paper we are going to discuss causes of anemia, signs and symptoms, homeopathic management, treatment and simple prevention measures.

Keywords: anemia, nutritional anemia, iron deficiency anemia, fatigue etc.

\section{Introduction}

The word Anemia is derived from ancient Greek which means "without blood" [1]. It is defined as a qualitative or quantitative deficiency of hemoglobin inside red blood cells. According to world health organization it defined as hemoglobin $(\mathrm{Hb})$ levels $<12.0 \mathrm{~g} / \mathrm{dl}$ in women and $<13.0 \mathrm{~g} / \mathrm{dl}$ in men ${ }^{[2]}$. However, normal $\mathrm{Hb}$ distribution varies with sex along with ethnicity and physiological status. Anemia is the most common blood disorder. There are several kinds of anemia, produced by a variety of underlying causes. In one third of patients, anemia is due to nutritional deficiency, including iron, folate, vitamin B12 deficiency; anemia in chronic disease accounts for about another one third of cases. In one third of patient's anemia cannot be explained by an underlying disease or by specific pathological process.

\section{Classification}

Anemia is classified according to mean corpuscular volume (MCV) \& reticulocyte count ${ }^{9}$. An accurate reticulocyte count is key to the initial classification of anemia. Reticulocytes are red cells that recently released from bone marrow. Reticulocyte count ranges from $1-2 \%$ and reflects the daily replacement of $0.8-1.0 \%$ of circulating red cell population. A reticulocyte provides a reliable measure of red cell production ${ }^{[2]}$. In the classification of anemia, the patient's reticulocyte count is compared with expected reticulocyte response.

The functional classification anemia is having three major categories ${ }^{[3]}$.

1. Hyperproliferative anemia (marrow production defect)

2. Maturation disorder (ineffective erythropoiesis)

3. Blood loss / hemolytic anemia (decreased red cell survival)

Hyperproliferative anemia: $75 \%$ of cases of anemia are hyperproliferative in nature. most of the hyperproliferative anemia cases are due to mild to moderate iron deficiency or inflammation ${ }^{[10]}$. This type of anemia can result from marrow damage, iron deficiency. It is more prevalent in renal failure patients.

Maturation disorder: Low reticulocyte production index, macro- microcytosis on smear, and abnormal red cell indices suggests a maturation disorder ${ }^{[11]}$. Nuclear maturation defects from results from vitamin B12 or folic acid deficiency, drug damage, or myelodysplasia. Alcohol is capable of producing macrocytosis and variable degree of anemia.

Hemolytic anemia: It is a disorder in which red blood cells are destroyed faster than they can be made ${ }^{[4]}$. Hemolytic anemia can occur in two conditions, they are inherited \& acquired. Two common causes of inherited type of anemia are sickle cell anemia \& thalassemia. Acquired anemia can caused due to bacterial or viral infections, blood cancers, 
auto immune disorders, an overactive spleen [12] (hypersplenism).

\section{Signs and Symptoms}

Anemia symptoms vary from mild to severe ${ }^{[13]}$. Patients who are having mild anemia may not experience any symptoms and those who have intense anemia include ${ }^{[5]}$ :

- Cheilosis sign-fissures in the corners of mouth

- Koilonychia-thin \& soft nails with concavity

- Due to lack of adequate blood supply to the brain and other tissues of the body patient may have poor concentration along with the restlessness of legs
- Shortness of breath

- General malaise

- Palpitations \& profuse sweating

- Pica

- Fatigue

- Pallor

- Conjunctival pallor

- Hepatosplenomegaly

- Chronic anemia may result in behavioral disturbances in children as a direct result of impaired neurological development in infants.

Table 1: Symptoms of Anemia

\begin{tabular}{|c|c|c|}
\hline Body Part & Symptoms & Severe Symptoms \\
\hline Eyes & Yellowing & -- \\
\hline Skin & Paleness, Coldness, Yellowing & -- \\
\hline Respiratory & Shortness of breath & -- \\
\hline Muscular & Weakness & -- \\
\hline Intestinal & Changed stool color ${ }^{[14]}$ & Fainting \\
\hline Central nervous system & Fatigue, Dizziness & -- \\
\hline Blood Vessels & Low blood pressure ${ }^{[15]}$ & Chest pain, Angina, Heart attack \\
\hline Heart & Palpitations, Rapid heart rate & C- \\
\hline Spleen & Enlargement & \\
\hline
\end{tabular}

\section{Diagnosis ${ }^{[5]}$}

Initially anemia can be diagnosed through physical examination by the physician as well as blood tests to identify the specific type of anemia.

- Blood test to know the levels of iron, vitamin B12, folic acid and vitamins and minerals ${ }^{[16]}$.

- Complete blood count which includes Red Blood Cell count (to determine the total number of RBCs \& size of the RBCs), Red blood cells indices, White blood cell count

Platelet count and Cell morphology ${ }^{[17]}$.

- Investigations that include:

- Bone marrow aspiration and biopsy

- Liver function test, kidney function test may be performed.

\section{Treatment}

Treatment is always depending on the cause ${ }^{[5]}$, type and severity of anemia.

- Iron, folic acid and vitamin B12 supplements.

- Dietary change

- Blood transfusion [18]

- Bone marrow transplant

\section{DIET}

In case of nutritional deficiency anemia certain foods can be added in daily diet ${ }^{[6]}$ such as

- Pulses and beans

- Leafy green vegetables

- White or red meat

- Seeds and nuts

- Eggs

- Fish and Tofu

- Dried Fruits

\section{Homoeopathic Management}

If anemia is caused by loss of blood or other fluids [7]: calcariacarbonica, carbo vegetabilis, hydrangea, Ferrum metallicum, phosphoric acid, Sulphur, Staphysagria, Nux vomica,

If anemia is caused by violent acute disease ${ }^{7}$ : calcariacarbonica, carbo vegetabilis, Natrum Muraticum, veratrum alb.

Alumina: Best suited remedy for anemia caused due to nutritional disturbances. chlorosis in young girls at puberty, scanty menses and pale. Craving for indigestible things ${ }^{[7]}$.

Argentum nitricum: shortness of breath, heart burn, irritative gastralgia, violent and irregular palpitations, irregular menses, rapid and excessive albuminuria, desire for sugar or candy.

Kali carbonicum: blood lacks red blood corpuscles. Young ladies at time of puberty have menstrual trouble on account of great weakness. Dropsy, lower backache, vertigo when turning head rapidly, frequent chilliness, every time patient goes out of doors ${ }^{[8]}$.

Pulsatilla nigricans: chloro-anemia women, always complains of feeling chilly, and still better fresh air, feels exhausted, all tissues relaxed, peevish, slow, phlegmatic temperament, after failure of iron and China. Agg -in heat, Amel -open air ${ }^{[8]}$.

Natrum Muraticum [7]: blood impoverished, anemia from loss of fluids, emaciation, skin rash, dry, yellow, great exhaustion from any little exertion of mind or body, palpitation with sensation as if a bird's wing were fluttering in left chest, pressure $\&$ distension of stomach ${ }^{[19]}$.

Natrum carbonium: pallid anemia with great debility, milky-white skin, emaciation, skin rash, nervousness and anxiety ${ }^{[20]}$.

Natrum Sulphuricum: Hydrogenoid constitution, depending upon dampness of weather or dwelling in damp 
houses; sycosis and hydraemia ${ }^{[21]}$.

Hydrastis: Atony, weakness, faintness and prostration from dyscrasic disorders injuring normal blood-formation; carcinoma etc., marasmus; expression dull; skin sallow, yellowish-white; bad effects from Merc ${ }^{[22]}$.

China officinalis: Complaints from loss of animal fluids, be it blood, semen, diarrhea, leucorrhea or over lactation; great debility, trembling, aversion to exercise; palpitations with rush of blood to head, and redness of face with cold hands; heaviness of head, with loss of sight, fainting and ringing in ears; sleeplessness; intolerance of fruits ${ }^{[23]}$.

Ferrum metallicum: Pure anemia with appearance of false plethora; face ashy Pale or greenish, becomes bright red in flushes; great paleness of mucous membranes; bellow's sound of the heart and anemic murmurs of the arteries and veins; vomiting as soon as food is taken, with relief of gastralgic pains, prostration with lethargic dullness; animal food not desired ${ }^{[24]}$.

\section{Prevention}

Healthy life style and well-balanced diet, regular exercise along with regular health checkups ${ }^{[25]}$.

\section{Conclusion}

Anemia can affect any age group, both the sex, predominately seen in children and women, malnourished persons, pregnant women and the people who are having chronic illness. If untreated it causes many complications ${ }^{[26]}$. By finding out the cause of the anemia and considering the medical history, lifestyle, peculiar particular symptoms of the patient can be treated by homoeopathic system of medicine and prevent further prognosis of the condition ${ }^{[27]}$.

\section{References}

1. Dr. Manisha Bhatia, "Anemia Homeopathy treatment guide" available at https://www.doctorbhatia.com/treatment/anemiahomeopathy-treatment-and-homeopathic-remedies/

2. Cappellini MD, Motta I. Anemia in Clinical PracticeDefinition and Classification: Does Hemoglobin Change with Aging? Semin Hematol 2015;52(4):261-9. doi: 10.1053/j.seminhematol.2015.07.006. Epub 2015 Jul 17. PMID: 26404438.

3. Fauci, Braunwald et al., "Harrison's Principles of Internal Medicine", McGraw Hill medical, $17^{\text {th }}$ edition, 2008, 1,

4. Hemolytic Anemia available at https://www.hopkinsmedicine.org/health/conditionsand-diseases/hemolytic-anemia

5. Blood disorders: Anemia, Pacific Heart, Lung \& Blood Institute available at https://www.phlbi.org/divisions/blood-disorders/anemia

6. Meredith Goodwin, Peter Lam, "What to know about anemia", Medical news Today, 2020 available at https://www.medicalnewstoday.com/articles/158800\#S ummary

7. Lilienthal Samuel, "Homoeopathic Therapeutics", B. Jain Publishers Pvt. Ltd.

8. Dr. Gopi KS, "Homoeopathy for Anemia", October 2016 available at https://www.linkedin.com/pulse/homoeopathy-anemia- dr-ks-gopi

9. Janus J, Moerschel SK. Evaluation of anemia in children. Am Fam Physician. 2010;81(12):1462-71. PMID: 20540485.

10. Wallerstein RO Jr. Laboratory evaluation of anemia. West J Med 1987;146(4):443-51. PMID: 3577135; PMCID: PMC1307333.

11. Prof. (Dr.) Niranjan Mohanty, "All in one Homoeopathic Materia Medica", B. Jain Publication pvt. Ltd 2018.

12. Cappellini MD, Motta I. Anemia in Clinical PracticeDefinition and Classification: Does Hemoglobin Change with Aging? Semin Hematol 2015;52(4):261-9. doi: 10.1053/j.seminhematol.2015.07.006. Epub 2015 Jul 17. PMID: 26404438.

13. Williams MD, Wheby MS. Anemia in pregnancy. Med Clin North Am 1992;76(3):631-47. doi: 10.1016/s00257125(16)30344-3. PMID: 1578961.

14. Dr. Joseph E Makaroon, Dr. Ali T Tahir et al., "Anemia workup" available at

https://emedicine.medscape.com/article/198475workup\#c11

15. Merlo CM, Wuillemin WA. Diagnostik und Therapie der Anämie in der Praxis [Diagnosis and therapy of anemia in general practice]. Praxis (Bern 1994) 2009;98(4):191-9. German. doi: 10.1024/16618157.98.4.191. PMID: 19224487.

16. Micronutrient deficiencies, (n.d) World Health Organisation available at https://www.who.int/healthtopics/anaemia

17. Ewelina Rogozinska, Marios Nicolaides et al., "Iron preparations for women of reproductive age with iron deficiency anemia in Pregnancy (FRIDA): a systemic review and network meta-analysis", The Lancet Haematology, 2021, 7

18. Miller JL. Iron deficiency anemia: a common and curable disease. Cold Spring Harb Perspect Med. 2013;3(7):a011866. Published 2013 Jul 1.doi:10.1101/cshperspect.a011866

19. Doshi J, Shah P, Patel G. Role of Homoeopathy in Anemia: Role of Homoeopathy in Anemia. National Journal of Integrated Research in Medicine 2019;10(1):43-46.

20. Dr. Dwivedi AK. Iron Deficiency Anemia \& Homeopathy medicines, Indian Journal of Applied Research 2019;9(12):13-18.

21. Jadhav SS, Tiwari P, Lata $\mathrm{K}$ et al. Iron deficiency anaemia \& Ferrum phosphoricum: A systematic review. International Journal of Research and Review 2019;6(2):83-91.

22. Shikha Yadav, Singh CB, Brijesh Singh, Anil Kumar, Singh NK, Effect of homeopathic drugs on growth and haemato-biochemical parameters of piglet anaemia, International Journal of 2017;15(3):161-164.

23. Ghulam Yaseen, Dr. A Cured Case of Aplastic Anemia by Homeopathy 2021. 10.13140/RG.2.2.33596.05762.

24. Khurana A, Mittal R, Rath P, Moorthy K, Taneja D, Singh U et al. Ferrum phosphoricum $3 \mathrm{X}$ and Ferrum metallicum $3 \mathrm{X}$ in the treatment of iron deficiency anaemia in children: Randomized parallel arm study. Indian J Res Homoeopathy 2020;14:171-8

25. Smith DL. Anemia in the elderly. Am Fam Physician. 2000;62(7):1565-72. PMID: 11037074.

26. Cases A, Egocheaga MI, Tranche S, Pallarés V, Ojeda 
R, Górriz JL et al. Anemiaen la enfermedad renal crónica: protocolo de estudio, manejo y derivación a Nefrología [Anemia of chronic kidney disease: Protocol of study, management and referral to Nephrology]. Aten Primaria 2018;50(1):60-64. Spanish. doi: 10.1016/j.aprim.2017.09.007. Epub 2017 Dec 7. PMID: 29224999 ; PMCID: PMC6837054.

27. Broadway-Duren JB, Klaassen H. Anemias. Crit Care Nurs Clin North Am 2013;25(4):411-26 v.

doi: 10.1016/j.ccell.2013.09.004. PMID: 24267278 